\title{
Building and validating an educational video for elderly individuals about fall risks
}

\author{
Construção e validação de vídeo educativo para idosos acerca dos riscos de queda \\ Construcción y validación de video educativo para ancianos sobre riesgos de caída
}

\section{Guilherme Guarino de Moura Sá ORCID: 0000-0003-3283-2656 \\ Ana Maria Ribeiro dos Santos ORCID: 0000-0002-5825-5335 \\ Nelson Miguel Galindo Neto" ORCID: 0000-0002-7003-165X \\ Khelyane Mesquita de Carvalho ORCID: 0000-0003-4270-3890 \\ Carla Danielle Araújo Feitosa' ORCID: 0000-0001-7347-6972 \\ Polyana Norberta Mendes' ORCID: 0000-0002-2765-0236}

'Universidade Federal do Piauí. Teresina. Piauí. Brazil. "Instituto Federal de Educação. Ciência e Tecnologia de Pernambuco. Pesqueira. Pernambuco. Brazil.

How to cite this article:

Sá GGM. Santos AMR. Galindo Neto NM. Carvalho KM.

Feitosa CDA. Mendes PN. Building and validating an educational video for elderly individuals about fall risks.

Rev Bras Enferm. 2020;73(Suppl 3):e20200010. doi: http://dx.doi.org/10.1590/0034-7167-2020-0010

\section{Corresponding author:}

Guilherme Guarino de Moura Sá E-mail: guilherme_mourasa@hotmail.com

EDITOR IN CHIEF: Antonio José de Almeida Filho ASSOCIATE EDITOR: Andrea Bernardes

Submission: 01-06-2020
Approval: 07-16-2020

\section{ABSTRACT}

Objective: to build and validate educational video for elderly individuals about fall risks. Methods: methodological study with video building. validated by 22 judges and assessed by 22 elderly individuals. Content was selected from the Fall Prevention Model and items from the Falls Risk Awareness Questionnaire. Items with an agreement greater than 0.80 were considered valid. verified through Content Validation Index (CVI) and binomial test. Results: building the video was guided by the Cognitive Theory of Multimedia Learning. Digital animation and audio narration were used. It lasted ten minutes and five seconds and included biological. socioeconomic. behavioral and environmental risks as well as precautions to avoid them. The $\mathrm{CVI}$ of judges had an average of 0.99 . and of elderly individuals. an average of 1.0. Conclusion: the video was built and validated for content and understanding and can be used to prevent falls in elderly individuals.

Descriptors: Accidental Falls; Health of the Elderly; Health Education; Educational Technology; Instructional Films and Videos.

\section{RESUMO}

Objetivo: construir e validar vídeo educativo para idosos acerca dos riscos de queda. Métodos: estudo metodológico com construção de vídeo. validado por 22 juízes e avaliado por 22 idosos. Selecionou-se o conteúdo a partir do Modelo de Prevenção de Quedas e itens do Questionário de Percepção dos Riscos de Queda. Consideraram-se válidos os itens com concordância superior a 0.80 . verificados por meio do Índice de Validação de Conteúdo (IVC) e teste binomial. Resultados: a construção do vídeo foi norteada pela Teoria Cognitiva da Aprendizagem Multimídia. Utilizou-se animação digital e narração em áudio. Possuiu duração de dez minutos e cinco segundos e contemplou riscos biológicos. socioeconômicos. comportamentais e ambientais. além de cuidados para evitá-los. O IVC dos juízes teve média de 0.99 e dos idosos média de 1.0. Conclusão: o vídeo foi construído e validado quanto ao conteúdo e compreensão e pode ser utilizado para prevenção de quedas em idosos. Descritores: Acidentes por Quedas; Saúde do Idoso; Educação em Saúde; Tecnologia Educacional; Filmes e Vídeos Educativos.

\section{RESUMEN}

Objetivo: construir y validar video educativo para personas mayores sobre riesgos de caídas. Métodos: estudio metodológico con video construcción. validado por 22 jueces y evaluado por 22 personas mayores. El contenido se seleccionó del Modelo de Prevención de Caídas y elementos del Falls Risk Awareness Questionnaire. Los artículos con acuerdo superior a 0.80 se consideraron válidos. verificados mediante el Índice de Validación de Contenido (IVC) y prueba binomial. Resultados: la construcción del video fue guiada por la Teoría Cognoscitiva del Aprendizaje Multimedia. Se utilizaron animación digital y narración de audio. Duró diez minutos y cinco segundos e incluyó riesgos biológicos. socioeconómicos. conductuales y ambientales. así como precauciones para evitarlos. EI CVI de los jueces tuvo un promedio de 0.99 y el de los ancianos. un promedio de 1.0. Conclusión: el video fue construido y validado en términos de contenido y comprensión y puede usarse para prevenir caídas en los ancianos. Descriptores: Accidentes por Caídas; Salud del Anciano; Educación en Salud; Tecnología Educacional; Películas y Videos Educativos. 


\section{INTRODUCTION}

Falls in elderly individuals are a public health concern. given their prevalence and consequences such as impaired functional independence. fear of falling. fractures. institutionalization. and death $^{(1-2)}$. It is estimated that $35 \%$ of people over 65 and $42 \%$ of those over 70 fall every year ${ }^{(3)}$ worldwide. Falls. unrelated to alcohol use or work activity. are the most common domestic accident among elderly individuals ${ }^{(4)}$.

Preventing falls involves the role of elderly individuals in reducing exposure to risks of falling. However. as a gap for such leading role and prevention. elderly individuals do not recognize themselves as vulnerable and do not identify the risks to which they are exposed ${ }^{(5)}$. This situational diagnosis should. therefore. become a motivating tool for conducting interventions that deal with the awareness of elderly individuals about fall risks. to collaborate for preventing health problems and self-care. In this regard. health education stands out as a necessary tool for primary prevention in the community ${ }^{(6)}$.

When considering health education as an assistance practice inherent to nursing. it is necessary for nurses to incorporate strategies that enhance educational care for this population. To that end. interventions based on health education to prevent falls in elderly individuals used different educational technologies such as booklet. manual. videos. and models; they have proved to be effective in identifying and reducing fall risks. in the knowledge and effort to prevent risky behaviors and greater willingness of elderly individuals to make changes in their homes ${ }^{(7)}$.

The technologies used for health education must consider the uniqueness of each person/group. However. the low level of literacy among elderly individuals is still a reality in Brazil and should be taken into account when deciding on the teachinglearning strategy to be implemented. ${ }^{(8)}$. Thus. it is necessary to use technological resources that overcome the difficulty of communication in the written form by elderly individuals and contribute to the knowledge translation of this audience.

Accordingly. the video is a tool capable of facilitating the educational process of elderly individuals. It allows presenting information from images and sounds that give this technological resource an attractive and dynamic character and arouses interest in learning the subject addressed ${ }^{(9)}$. Although using video with elderly individuals has been shown to be effective in preventing falls in countries such as Australia and the United States. there is a gap in the scientific literature about the existence and use of this type of technology with elderly individuals in $\mathrm{Brazi}^{(7)}$.

Therefore. when considering the severity of falls and the need to prevent them; the effectiveness of video in preventing falls in elderly individuals; and the aforementioned gap. there is a need to build and validate a video about fall risks for elderly individuals in Brazil. which includes aspects that favor multimedia learning. highlighting the unprecedented character of this study.

Availability of such a technological resource contributes to health education actions in nursing and other members of the multidisciplinary team. Moreover. it can be used by elderly individuals. without professionals. Therefore. videos provide an expansion of health opportunities. participation and safety for elderly individuals. Furthermore. the possibility of contributing to reducing the number of falls in this population is also considered.

\section{OBJECTIVE}

To build and validate an educational video for elderly individuals about fall risks.

\section{METHODS}

\section{Ethical aspects}

This study complied with Resolution 466/12 and was approved by the Research Ethics Committee of Universidade Federal do Piauí.

\section{Design. place of study. and period}

This is a methodological study composed of the building of an educational video on fall risks for elderly individuals. validation by judges and assessment by elderly individuals. representatives of the target audience. Validation by judges took place from May to June 2019; video assessment by elderly individuals took place between June and July 2019 in the municipality of Bom Jesus. state of Piauí.

\section{Population. or sample; inclusion and exclusion criteria}

Video content validation took place through assessment by nurse judges who specialize in geriatrics. gerontology. and falls. The decision to include these professionals was made when considering their intrinsic role as health educators who develop and use educational technologies for elderly individuals; and its importance in the therapeutic communication process with this public. which increases the chances of nurses knowing the necessary specificities of educational material aimed at this population. From this perspective. even though other health professionals provide assistance to elderly individuals. nurses' role differs from the others. To assess content. experience and updating on fall risks. knowledge of the health education process and of building educational materials for elderly individuals are relevant.

Sample size was calculated from the formula for finite population $n=Z a^{2} . P(1-P) / e^{2}$. "Za" represents the level of confidence; " $\mathrm{P}$ " represents the expected proportion of judges who agree with the item; and " $\mathrm{e}$ " represents the expected difference. Thus. the following values were used: $\mathrm{Za}^{2}=95 \%$. $\mathrm{P}=85 \%$. $\mathrm{e}=15 \%$. which resulted in 22 judges $^{(10)}$.

To be a judge. each professional should meet at least one requirement of three selection criteria suggested by the literature $^{(11)}$ : skill / knowledge in the topic of interest (requirement: PhD. master or specializes in field. with graduate work orientation in field. speaker in a national or international scientific event on the field); skill/knowledge in a particular type of study (requirement: development of studies on building. or assessing educational technologies. or participation in newsstands on the subject. or have articles published on falls in elderly individuals. or educational technologies); skill/knowledge acquired by professional experience (requirement: teaching experience in gerontological nursing. or care experience in caring for elderly individuals). Individuals who sent the assessment instrument incomplete were excluded. 
For video assessment by the target audience. the formula for finite population was also used. The formula resulted in 22 elderly individuals registered in a Family Health Strategy team. which contained 90 registered elderly individuals. To select the team. a draw was carried out. with the aid of the R software. among the teams in the municipality.

Elderly individuals were selected by simple random sampling. from a list with names organized in alphabetical order and numbered in ascending order. From all names drawn. nurses and Community Health Agents were consulted to verify the potential of elderly individuals' eligibility regarding the possibility of getting around the Basic Health Unit (UBS). since it was the place of data collection. Moreover. there was access to the medical records of elderly individuals for triangulation of information.

Elderly people with good cognitive status. assessed using the Mini Mental State Examination (MMSE). with cut-off points adjusted for years of education: 20 points - illiterate; 25 points - education from one to four years; 26.5 points - from five to eight years; 28 points - from nine to 11 years; 29 points - over 11 years ${ }^{(12)}$. Elderly people who were physically unable to get around the BHU were excluded. It is noteworthy that the first 22 elderly individuals selected met the inclusion criteria.

\section{Study protocol}

Building the video followed the methodological framework recommendations to develop audiovisual technologies and took place in three phases: pre-production. production. and postproduction. In pre-production. a storyboard was built. which consists of presenting the chronological flow of the illustrations of each scene to be produced and promotes a preview of the final product layout ${ }^{(13)}$.

Content. present in the storyboard. addressed fall risks and was selected from the World Health Global Report on Falls Prevention in Older Age ${ }^{(14)}$. Furthermore. items from the Falls Risk Awareness Questionnaire (FRAQ-Brazil) were considered. as it is a validated instrument that assesses the perception of elderly individuals about such risks ${ }^{(15)}$.

The storyboard was built by a communications company composed of professionals graduated in design that specialize in building videos in digital animation format. This form of video was chosen because it favors narration and demonstration of conduct; favors organization of information in sequence and temporal order; makes it possible to add visual and sound resources; and draws the viewer's attention by the interaction between playful and real(9).

Images were created by means of vector illustration and followed by written text and previous description of animation action/composition. below each scene. The storyboard had 68 screens and was diagrammed with the aid of Corel Draw X7.

After building the video storyboard. content validation was carried out by nurse judges. To that end. judges were recruited by "snowball" sampling. Initially. snowball sampling occurred from the nomination by professors of the Graduate Program in Nursing at a public educational institution in Teresina. through which electronic addresses of nurses with expertise in the field of interest were obtained. After each referral. the professionals' résumés were assessed to verify compliance with the inclusion criteria.

Contacts were obtained from nurses from all regions of Brazil so that invitations were sent. by email. to 60 professionals who met the established criteria. These professionals received. via Google form: a) an Informed Consent Form (ICF); b) a form to characterize the profile of judges. which contained 14 questions about professional training and performance in the area of interest; $c$ ) a storyboard; d) an Educational Content Validation Instrument in Health (Instrumento de Validação de Conteúdo Educacional em Saúde. abbreviated IVCES). used to assess educational content in health. The IVCES has 18 items. divided into three domains (objectives. structure/presentation. and relevance). in which each item is assessed according to agreement and relevance by using a Likert scale (adequate. partially adequate. and inadequate)(16).

Judge recruitment ended when the first 22 professionals sent a response. with a completed form. Therefore. nurses from the states of Alagoas. Ceará. Minas Gerais. Pará. Piauí. Rio de Janeiro. and Rio Grande do Sul participated in this assessment.

All adjustments requested by judges were met and focused on increasing letter size in some scenes and reformulating excerpts from the narration. with a view to making them more understandable by elderly individuals. It should be noted that no modifications to illustrations were requested.

After completing storyboard validation. the video production phase began. Images animation and audio narration were used. Vectorized images were animated by Adobe After Effects CS6. The audio consisted of a light informative voiceover performed by a professional narration company. and edited in the Adobe Audition CS6 program.

When considering that the video proposes to contribute to health teaching. its building was guided by the Cognitive Theory of Multimedia Learning (CTML). According to this theory. building knowledge occurs from integrating the learner's prior knowledge with new content. and this occurs through simultaneous encouragement of different sensory channels (verbal/auditory and visual/pictorial). Thus. multimedia becomes a robust educational strategy as it allows simultaneous presentation of images and verbal content ${ }^{(17)}$.

The video covered the 12 principles of CTML. which guide the planning and creation of multimedia: coherence principle (excluding images. words and sounds that are not necessary); signaling principle (presence of signs that direct attention); redundancy principle (use of animation and narration instead of animation. narration and caption); principle of spatial contiguity (words and corresponding images appear spatially close); temporal contiguity principle (corresponding words and images appear at the same time); segmentation principle (information in chunks); pre-training principle (general presentation of content before details); modality principle (animation and narration instead of animation and written text); multimedia principle (use of words and images instead of just words); personalization principle (words in conversational style instead of formal style); voice principle (narration with human voice); image principle (the narrator image is not essential) ${ }^{(17)}$.

In post-production. video editing. finalization and final organization were carried out. For converting image and audio edits to 
video. Adobe Media Encoder CS6 was used. The video was finished in a Full HD standard. measuring 1920x1080px. 29.97 frames per second (fps). The final encoding format was MP4. and the devices selected for storage were DVD. flash drive. and notebook.

After completing the post-production phase. the video was assessed by elderly individuals recruited by lot. based on a list provided by the health team nurse. with the name of those potentially eligible. Elderly individuals were approached during a home visit carried out by the researcher and CHA to clarify the objective of the research. and an invitation to attend $\mathrm{BHU}$ to watch and assess the video on a previously scheduled date was made.

Subgroups were formed with a maximum of ten elderly individuals. in order to minimize the waiting burden when applying the instruments. tiredness and/or discouragement. Thus. three subgroups were formed on different days so that two elderly individuals participated in two and eight participated in one. Elderly individuals were approached in the $\mathrm{BHU}$ meeting room to explain the study. sign the ICF. individual interview to assess cognitive status and expose the video.

The video was played using a Data Show device and audio via a high-quality power box (Rms: $80 \mathrm{w}$ ) with a frequency of 100 $\mathrm{Hz}-20 \mathrm{KHz}$. Elderly individuals were sat on chairs in front of the projector. Soon after. they were interviewed to fill in an adapted version of the Suitability Assessment of Materials (SAM). to envisage the particularities of video educational material ${ }^{(18)}$. The instrument included 18 questions about content. understandable language. illustrations. layout and presentation. encouragement/motivation of learning and cultural adequacy. and contained space to take note of suggestions. Each item was assessed as excellent. adequate. or not adequate.

\section{Analysis of results. and statistics}

Absolute and relative frequency was used to present characterization of judges and elderly individuals. Content validation was performed by applying the Content Validation Index (CVI) calculations: Item-level Content Validity Index (I-CVI). to determine the judges' agreement for each item; Scale-level Content Validity Index. Average Calculation Method (S-CVI/AVE). to determine the proportion of items that obtained agreement from each judge; Scale-level Content Validity Index (S-CVI). to establish the average of the S-CVI/AVE. An index equal to or greater than 0.80 was considered desirable for content validation ${ }^{(19)}$. Furthermore. R. 3.1.1 was used to apply the binomial test. to statistically verify agreement equal to or greater than 0.80 . A significance level of $5 \%$ was adopted.

\section{RESULTS}

The video was entitled "Risco de queda: não caia nessa" (freely translated as Fall risk: don't fall for it). It lasted ten minutes and five seconds and included an opening; questioning about previous falls; presentation of the video's purpose; information on the consequences of falls; presentation of risks and care not to fall.

The fall risks envisaged were: biological risks (age. sex and diseases); socioeconomic risks (inadequate housing and living alone); environmental risks (uneven sidewalks. carpets. loose objects and wires. pets. uneven chairs. insufficient lighting. stairs without handrails. slippery floors. beds or tall hammocks. bathroom without grab bars and low toilet); behavioral risks (use of multiple medications. alcohol consumption. physical inactivity. fear of falling. inappropriate shoes. getting up fast. walking in the dark and/or with socks. incorrect use of walking sticks/walkers and climbing on another piece of furniture to reach higher places).

To promote multimedia learning. the CTML coherence principle was contemplated by using visual and sound content related to the objective of instruction. The signaling principle was followed. as arrows. symbols. and prominent colors were used. in addition to changes in intonation of the narrator's voice to draw attention to a certain content. The redundancy principle was used with animation and narration. without subtitles. Spatial and temporal contiguity occurred. since corresponding words and images were presented in the same scene. and animations and narration took place simultaneously.

The segmentation principle was considered. since information was presented in chunks so that each risk was addressed individually. The pre-training principle was used when presenting the video's purpose and the consequences of falls. The modality principle was followed. since animation presentation was associated with narration. and not with written texts. The multimedia principle was observed. because images and narration are used. The personalization principle was applied based on use of simple and informal popular language. adapted to the target audience. The voice principle was used. since human voice narration was used. The image principle was used. since the narrator image was not exposed.

To demonstrate the fall risks for in both sexes. characters were an elderly man and an elderly woman. Figure 1 shows some scenes from the video.

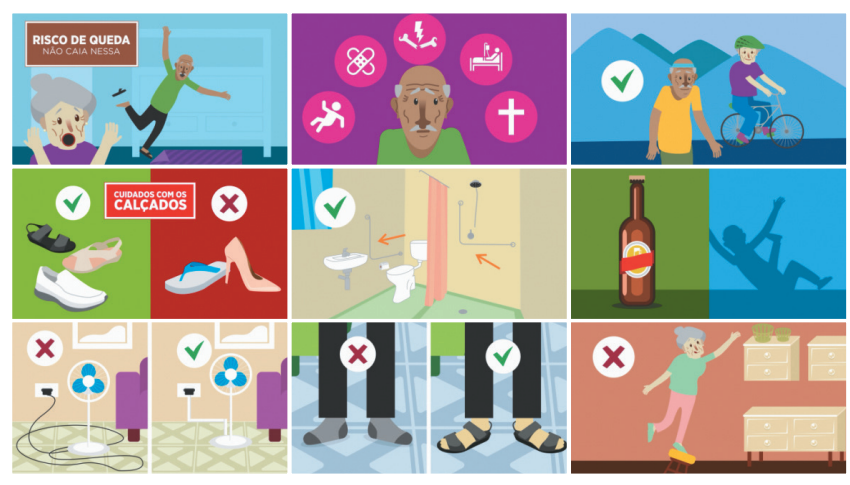

Note: cuidado com os calçados - watch your shoes; Risco de queda. não caia nessa - Fall risk don't fall for it. All sentences are in Brazilian Portuguese because this instrument has not been validated to English. therefore this is a free translation.

Figure 1 - Scenes of "Risco de queda: não caia nessa". Bom Jesus. Piauí. Brazil. 2019

Content validation was performed by 22 nurse judges. of whom 11 (50.0\%) held a PhD and 11 (50.0\%) had a master's degree. Regarding professional experience. 18 (81.8\%) had care experience with elderly individuals and 18 (81.8\%) had teaching experience in the field of elderly health. With regard to scientific production. 20 (90.9\%) had published a scientific article in a journal on elderly health and 11 (50.0\%) on a fall in elderly individuals. Furthermore. 13 (59.1\%) had experience in building educational materials for elderly individuals and 16 (72.7\%) participated in the assessment of content of educational materials. 
Of the 18 items assessed by judges. 17 had unanimous agreement. with an I-CVI of 1.0. Only the item "adequate text size". referring to structure/presentation. was considered inappropriate by two judges $(I-C V I=0.90)$. Although other judges judged the item in question as adequate or partially adequate. the requested modification was met.

It is observed that there was agreement by all judges on relevant items. when considering that the video content was adequate to the teaching-learning process. encourages behavior change. has language appropriate to the target audience and that the information was correct. objective and clarifying (Table 1).

Table 1 - Judges' agreement regarding objectives. structure/presentation. and relevance. Bom Jesus. Piauí. Brazil. 2019

\begin{tabular}{|c|c|c|c|c|}
\hline Item & $\begin{array}{c}\text { Adequate } \\
\text { n (\%) }\end{array}$ & $\begin{array}{c}\text { Partially } \\
\text { adequate } \\
\text { n (\%) }\end{array}$ & $\mathbf{I}-\mathbf{C V I} \mathbf{I}^{*}$ & $\boldsymbol{p}^{* *}$ \\
\hline \multicolumn{5}{|l|}{ Objectives } \\
\hline 1. Proposed theme included & $22(100.0)$ & $0(0.0)$ & 1 & 1 \\
\hline 2. Adequate to teaching-learning & $19(86.4)$ & $3(13.6)$ & 1 & 1 \\
\hline $\begin{array}{l}\text { 3. Doubts clarified on the topic } \\
\text { addressed }\end{array}$ & $21(95.5)$ & $1(4.5)$ & 1 & 1 \\
\hline 4. Reflection on the theme & $22(100.0)$ & $0(0.0)$ & 1 & 1 \\
\hline $\begin{array}{l}\text { 5. Behavior change } \\
\text { encouragement }\end{array}$ & $20(90.9)$ & $2(9.1)$ & 1 & 1 \\
\hline \multicolumn{5}{|l|}{ Structure/presentation } \\
\hline $\begin{array}{l}\text { 6. Language suitable for the target } \\
\text { audience }\end{array}$ & $17(77.3)$ & $5(22.7)$ & 1 & 1 \\
\hline $\begin{array}{l}\text { 7. Language appropriate to } \\
\text { educational material }\end{array}$ & $21(95.5)$ & $1(4.5)$ & 1 & 1 \\
\hline 8. Interactive language & $20(90.9)$ & 29.1) & 1 & 1 \\
\hline 9. Correct information & $22(100.0)$ & $0(0.0)$ & 1 & 1 \\
\hline 10. Objective information & $18(81.8)$ & $4(18.2)$ & 1 & 1 \\
\hline 11. Clarifying information & $20(90.9)$ & $2(9.1)$ & 1 & 1 \\
\hline 12. Necessary information & $20(90.9)$ & $2(9.1)$ & 1 & 1 \\
\hline 13. Logical sequence of ideas & $21(95.5)$ & $1(4.5)$ & 1 & 1 \\
\hline 14. Current theme & $22(100.0)$ & $0(0.0)$ & 1 & 1 \\
\hline 15. Appropriate text size & $15(68.2)$ & $5(22.7)$ & 0.90 & 0.86 \\
\hline \multicolumn{5}{|l|}{ Relevance } \\
\hline 16. Learning encouragement & $22(100.0)$ & $0(0.0)$ & 1 & 1 \\
\hline $\begin{array}{l}\text { 17. Knowledge contribution in } \\
\text { the field }\end{array}$ & $22(100.0)$ & $0(0.0)$ & 1 & 1 \\
\hline 18. Interest arousal in the topic & $21(95.5)$ & $1(4.5)$ & 1 & 1 \\
\hline
\end{tabular}

Of the 22 judges. 20 agreed with all items (S-CVI/AVE=1.0). The remaining two judges disagreed with only one item $(94.4 \%$ agreement and S-CVI/AVE=0.94). The S-CVI for content validation was 0.99 . Therefore. the video content was validated in terms of objectives. structure/presentation. and relevance.

The final version was assessed by 22 elderly individuals from the community. of whom 13 (59.0\%) were women. with an average age of 73.4 years old. all retired. 11 (50.0\%) married. seven (31.8\%) widowed and four (18.2\%) single. The average years of study was 2.5 years. Of the participating elderly individuals. eight (36.4\%) had fallen at least once in the past year.

According to assessment of elderly individuals. the video was considered comprehensible so that all considered items related to content. understandable language. illustrations. layout and presentation. encouragement/motivation of learning and cultural adequacy. Therefore. all items had I-CVI = 1.0. The S-CVI/AVE of the assessment of elderly individuals was 1.0 and the S-CVI of 1.0.

\section{DISCUSSION}

Building and validating an educational video for elderly individuals about fall risks contributes to the promotion of active aging. since the prevention actions covered in the video optimize opportunities for health. participation. and safety. Availability of this technological resource favors reaching the WHO fall prevention goals to increase awareness and identification of fall risks by elderly individuals ${ }^{(14)}$. Moreover. it envisages the goals of the Brazilian National Health Science. Technology and Innovation Policy and the Ministry of Health's Research Priorities Agenda (Política Nacional de Ciência. Tecnologia e Inovação em Saúde e da Agenda de Prioridades de Pesquisa do Ministério da Saúde). Such goals highlight the need for investment in research to develop self-care technologies and name the health of elderly individuals as a priority for health research in Brazil(20-21).

When considering that falls are an event of multifactorial cause and that such factors must be recognized by the elderly population for success in prevention actions. it is relevant that the video has considered biological. socioeconomic. environmental and behavioral risks. These contents were also covered in a manual educational technology built and validated in Europe ${ }^{(22)}$. This aspect allows the technology built and validated in this study to be used in the routine of primary health care services. Therefore. using video becomes an educational tool that contributes to promote holistic care to prevent falls and expands the possibilities of preventive interventions with elderly individuals.

In relation to biological risks. it is relevant to present them to the elderly public in educational technology. considering the higher prevalence of falls in women. older and among those with chronic diseases ${ }^{(23)}$. As these are non-modifiable conditions. independent and autonomous people with good physical-motor performance may underestimate the physiological changes in senescence and the pathophysiology of chronic diseases. which contribute to falls. Moreover. it is pertinent to recognize that being a woman. older elderly person and/or having chronic diseases increases the probability of falling so that people belonging to such groups realize the need for prevention and adopt behaviors to reduce the chances of this accident to occur.

The socioeconomic risks of falls. related to inadequate housing and living alone. were also presented in the video. Adapting the architecture of elderly's homes is important in preventing these accidents. Throughout life. the natural wear and tear of the human body requires new physical efforts. which become difficult to overcome in housing disproportionate to the condition of mobility and routine of elderly individuals ${ }^{(24)}$. Despite the low socioeconomic conditions that limit performing home adjustments/reforms. the knowledge of this risk by elderly individuals is essential to think about solutions. On the risk of living alone. a study conducted in Iran found that the occurrence of falls was significantly higher among elderly individuals who lived in this condition ${ }^{(25)}$. Therefore. it is relevant to inform that the fact of not living with a family member/companion represents greater fall risks so that those who fit this reality expand prevention behaviors.

Environmental risks also contribute significantly to the occurrence of falls. Despite this. exposure of elderly individuals to these risks is notable. according to research conducted in Portugal. The results showed that all participating elderly individuals had at least 
one rug at home and an unstable piece of furniture. and that $61.3 \%$ took care of pets inside home ${ }^{(26)}$. Thus. it is perceived the relevance of the educational video to envisage information about the different environmental risks for elderly individuals so that they can make changes in their places of living and become information multipliers.

Another chunk of information presented in the video was related to behavioral risks. which are potentially modifiable lifestyle habits such as sedentary lifestyle. drinking alcohol and climbing another piece of furniture to reach higher places. Healthy habits must be exhaustively disseminated. reinforced. made feasible and promoted with elderly individuals. as important for health promotion in the multidimensionality of aging and for reducing fall risks and cardiovascular. oncological. locomotor and mental disorders ${ }^{(27)}$. From this perspective. video can become an intensifier of verbal guidance by professionals about changes in behaviors that can prevent falls.

The video content. assessed by judges. was considered adequate to the teaching-learning process. This aspect was also assessed in the validation of other technologies for elderly individuals. such as booklet. interactive internet platform and computer application ${ }^{(28-30)}$. Further experimental studies should assess the effectiveness of using educational video in preventing falls and provide robust scientific evidence about its use for health education.

During the building of health education materials for elderly individuals. it is necessary to value strategies that favor their specific teaching-learning process. They have characteristics inherent to aging that require adjustments in technology. Visual. auditory. and cognitive changes of senescence demand characteristic technologies. namely: carefully clear texts; objective and short; simple language; short chunks of information; limitation of text movements; images that motivate learning; sufficient image and letter sizes to facilitate viewing; use of sans serif fonts; greater spacing between lines of text; increased contrast; non-blinking animations and texts ${ }^{(31)}$.

According to judges' assessment. the video had correct. objective and enlightening information. This finding corroborates research carried out in Portugal and Korea. Such research developed educational material for elderly individuals and obtained similar agreement between evaluators regarding content accuracy. objectivity. and clarification ${ }^{(22.24)}$. This finding was also observed in a Brazilian study that built and validated a booklet for HIV/AIDS prevention in elderly individuals ${ }^{(32)}$. These results demonstrate the importance of content assessment being done by professionals with expertise in the area of interest. as they contribute to the material containing correct. objective information and with the necessary highlights to ensure clarity of the content. ${ }^{(9)}$.

Judges also agreed that the video's content encourages behavioral change. Regarding the effectiveness of educational technologies to modify behaviors. a study conducted in the United States showed that the use of video was effective in improving the effort of elderly individuals to prevent fall risk behaviors ${ }^{(33)}$. This aspect is important for the effective use of this resource in preventing falls. since it goes beyond the role of improving knowledge or multiplying information. and can impact/reduce the number of falls. if spectators adopt new behaviors.

All modifications suggested by judges were about reformulating excerpts from the video narration and increasing the lyrics. These changes were also made in a Brazilian study that built and validated a booklet for elderly individuals about sleep hygiene ${ }^{(28)}$. When considering that technologies aimed at health education should take into account the popular context of the target audience ${ }^{(34)}$. adaptations in the text were relevant to not make the language confusing and incomprehensible. in addition to making visualization difficult. Therefore. with the modifications made. we sought to create an attractive layout. with content presented in a clear and simple way. so that the material was suitable for health education for elderly individuals. This aspect was corroborated by assessment of elderly individuals. who believed that the video had understandable language. boosts learning and is culturally appropriate.

When considering that the video was produced for the health education of elderly individuals. it became necessary that. in addition to judges. representatives of the target audience assess the material. This assessment was important because it made possible the suggestions of the people for whom the technology was intended. in a way that allows correcting misunderstandings and making adaptations. Studies carried out in the United States and Germany have shown that educational technologies built. despite being assessed by professionals. were misunderstood by the target audience ${ }^{(35-36)}$.

Regarding assessment of all illustrations used in the video. elderly individuals agreed that they helped to understand the content. Assessment of this criterion was also carried out in other Brazilian studies. which built educational materials with illustrations ${ }^{(9.28 .37)}$. When considering the low educational level of elderly individuals. it is clear that using illustrations can increase the chances of including illiterate elderly individuals. since they favor understanding of information. Using illustrations in the video. therefore. allows visual association. learning. memorization and building specific skills ${ }^{(38)}$. In this regard. multimedia information allows representing the educational. social and economic contexts of the public for whom it is intended. In this sense. they present possibilities of breaking barriers to accessing health information related to education. Thus. using video can have greater adherence by elderly individuals.

Images and texts. which made the video compatible with use for elderly individuals. were created according to CTML. According to this theory. organization of words and images is relevant for processing in verbal and visual working memory and integrating verbal and visual representations with each other with prior knowledge ${ }^{(17)}$. Therefore. it is highlighted that. building educational technologies in health needs theoretical foundation. as it enhances the achievement of the expected educational objective ${ }^{(7)}$.

\section{Study limitations}

Video assessment only by elderly individuals from the community is a limitation of this study. which may differ from the results obtained if the technology is assessed by institutionalized elderly individuals.

\section{Contributions to nursing. health. and public policies}

Building and validating an educational video about fall risks for elderly individuals favors the advancement of scientific knowledge in gerontology. Making this educational technology available will contribute to dissemination of care information. Moreover. the theoretical basis. technical and scientific rigor for content validation and assessment of comprehension by the target 
audience supports using video during health promotion actions in the community. teaching. research. and extension activities.

When considering the relevance of nurses' educational care. video emerges as a technological resource that can be incorporated into educational strategies already developed in the community. In this study. a replicable method of methodological research is also available. which can be used by nursing to develop other educational technologies for elderly individuals.

\section{CONCLUSION}

The educational video for elderly individuals about fall risks was built and considered valid in terms of content by nurse judges; and was assessed as understandable by elderly individuals representing the target audience. The final version consisted of digital animation. audio narration. and it was ten minutes and five seconds long. It addressed biological. socioeconomic. behavioral and environmental risks for falls and precautions to avoid them. The video structure included the CTML principles.

Content validation had an S-CVI of 0.99 and $100 \%$ agreement on 17 items. regarding objectives. structure/presentation and relevance. The item that did not obtain unanimous agreement. among nurse judges. was related to the text size. in which the agreement was $86 \%$. Elderly individuals considered the video adequate in terms of content. language. illustration. layout and presentation. encouragement/motivation of learning and cultural adequacy. with $100 \%$ agreement and S-CVI of 1.0.

The video is relevant and is a technological teaching resource to be used by nursing and other health professionals in health education actions aimed at the elderly population. However. the need to investigate the effectiveness of using video in improving the perception of fall risks in elderly individuals stands out.

\section{REFERENCES}

1. Khow KSF. Visvanathan R. Falls in the aging population. Clin Geriatr Med. 2017;33(3):357-68. doi: 10.1016/j.cger.2017.03.002

2. Sá GGM. Santos AMR. Functional independence of elderly patients who fell: a follow-up study. Rev Bras Enferm. 2019;72(6):1715-22. doi: 10.1590/0034-7167-2018-0845

3. World Health Organization (WHO). Falls. Fact sheet $N^{\circ}$ 344. [Internet]. 2012 [cited 2019 Dec 10]. Available from: http://www.who.int/ mediacentre/factsheets/fs344/en/

4. Cox S. Roggenkamp R. Bernard S. Smith K. The epidemiology of elderly falls attended by emergency medical services in Victoria. Australia. Injury. 2018;49(9):1712-19. doi: 10.1016/j.injury.2018.06.038

5. Chehuen Neto JA. Braga NAC. Brum IV. Gomes GF. Tavares PL. Silva RT. et al. Awareness about falls and elderly people's exposure to household risk factors. Ciênc Saúde Coletiva. 2018;23(4):1097-104. doi: 10.1590/1413-81232018234.09252016

6. Mallmann DG. Galindo Neto NM. Sousa JC. Vasconcelos EMR. Health education as the main alternative to promote the health of the elderly. Ciênc Saúde Coletiva. 2015;20(6):1763-72. doi: 10.1590/1413-81232015206.02382014

7. Sá GGM. Silva FL. Santos AMR. Nolêto JS. Gouveia MTO. Nogueira LT. Technologies that promote health education for the community elderly: integrative review. Rev Latino-Am Enfermagem. 2019;27:e3186. doi: 10.1590/1518-8345.3171.3186

8. Campos ACV. Ferreira EF. Vargas AMD. Gonçalves LH. Healthy aging profile in octogenarians in Brazil. Rev Latino-Am Enfermagem. 2016;24:e2724. doi: 10.1590/1518-8345.0694.2724

9. Galindo-Neto NM. Alexandre ACS. Barros LM. Sá GGM. Carvalho KM. Caetano JÁ. Creation and validation of an educational video for deaf people about cardiopulmonary resuscitation. Rev Latino-Am Enfermagem. 2019;27:e3130. doi: 10.1590/1518-8345.2765.3130

10. Lopes MVO. Silva VM. Araujo TL. Methods for establishing the accuracy of clinical indicators in predicting Nursing Diagnoses. Int J Nurs Knowl. 2012;23(3):134-9. doi: 10.1111/j.2047-3095.2012.01213.x

11. Jasper MA. Expert: a discussion of the implications of the concept as used in nursing. J Adv Nurs. 1994;20(4):769-76. doi: 10.1046/j.1365-2648.1994.20040769.x

12. Brucki SMD. Nitrini R. Caramelli P. Bertolucci PHF. Okamoto IH. Suggestions for utilization of the mini-mental state examination in Brazil. Arq Neuro-Psiquiatr. 2003;61(3b)777-81. doi: 10.1590/S0004-282X2003000500014

13. Kindem G. Musburger RB. Introduction to media production: from analog to digital. 3. ed. Boston: Focal Press; 2005.528 p.

14. World Health Organization (WHO). WHO Global Report on Falls Prevention in Older Age. [Internet]. Geneva; 2007 [cited 2019 Dec 11]. Available from: https://www.who.int/ageing/publications/Falls_prevention7March.pdf

15. Lopes AR. Trelha CS. Translation. cultural adaptation and evaluation of the psychometric properties of the Falls Risk Awareness Questionnaire (FRAQ): FRAQ-Brazil. Braz J Phys Ther. 2013;17(6):593-605. doi: 10.1590/S1413-35552012005000128

16. Leite SS. Afio ACE. Carvalho LV. Silva JM. Almeida PC. Pagliuca LMF. Construction and validation of an Educational Content Validation Instrument in Health. Rev Bras Enferm. 2018;71(suppl 4):1635-41. doi: 10.1590/0034-7167-2017-0648

17. Mayer RE. The Cambridge handbook of multimedia learning. [Internet] New York: Cambrindge University Press; 2014 [cited 2019 Dec 11 ]. Available from: https://assets.cambridge.org/97811070/35201/frontmatter/9781107035201_frontmatter.pdf

18. Sousa CS. Turrini RNT. Poveda VB. Translation and adaptation of the instrument "suitability assessment of materials" (SAM) in to portuguese. Rev Enferm UFPE [Internet]. 2015 [cited 2019 Dec 11];9(5):7854-61. Available from: https://periodicos.ufpe.br/revistas/revistaenfermagem/ article/view/10534/11435 
Building and validating an educational video for elderly individuals about fall risks Sá GGM, Santos AMR, Galindo Neto NM, Carvalho KM, Feitosa CDA, Mendes PN.

19. Polit D. Beck CT. The Content Validity Index: are you sure you know what's being reported? Critique and recommendations. Res Nurs Health[Internet]. 2006 [cited 2019 Dec 11];29(5):489-97. Available from: https://www.ncbi.nlm.nih.gov/pubmed/16977646

20. Ministério da Saúde (BR). Secretaria de Ciência. Tecnologia e Insumos Estratégicos. Departamento de Ciência e Tecnologia. Política nacional de ciência. tecnologia e inovação em saúde[Internet]. Brasília; 2008[cited 2019 Dec 11]. Available from: http://bvsms.saude.gov.br/bvs/ publicacoes/Politica_Portugues.pdf

21. Ministério da Saúde (BR). Secretaria de Ciência. Tecnologia e Insumos Estratégicos. Departamento de Ciência e Tecnologia. Agenda de prioridades de pesquisa do Ministério da Saúde. [Internet]. Brasília; 2018[cited 2019 Dec 11]. Available from: http://bvsms.saude.gov.br/bvs/ publicacoes/agenda_prioridades_pesquisa_ms.pdf

22. Andrade I. Silva C. Martins AC. Application of the Health Literacy INDEX on the development of a manual for prevention of falls for older adults. Patient Educ Couns. 2017;100(1):154-9. doi: 10.1016/j.pec.2016.07.036

23. Park D. Jo H. Yoon CH. Lee ES. Oh M. Lee CH. Fall risk assessment of rural elderly population in Korea. Ann Rehabil Med. 2019;43(3):269-78. doi: 10.5535/arm.2019.43.3.269

24. Jang M. Lee Y. The effects of an education program on home renovation for fall prevention of Korean older people. Educ Gerontol. 2015;41(9):653-69. doi: 10.1080/03601277.2015.1033219

25. Mouodi S. Bijani A. Hosseini SR. Hajian-Tilaki K. Gender differences in the health status of elderly living alone compared to those who are not alone: evidence of the AHAP study. North of Iran. Caspian J Intern Med[Internet]. 2016 [cited 2019 Dec 12];7(2):126-32. Available from: https://www.ncbi.nlm.nih.gov/pmc/articles/PMC4913716/

26. Oliveira T. Baixinho CL. Henriques MA. Multidimensional risk of falls in elderly. Rev Bras Promoç Saúde. [Internet]. 2018 [cited 2019 Dec 12];31(2):1-9. Available from: https://periodicos.unifor.br/RBPS/article/view/7058

27. Oliveira SLF. Francisco TJ. Cesar NA. Lima PR. Risk factors for falls in elderly homes: a look at prevention. Braz J Health Rev. 2019;2(3):1568-95. doi: 10.1590/S0080-623420140000300021

28. Carvalho KM. Figueiredo MLF. Galindo Neto NM. Sá GGM. Construction and validation of a sleep hygiene booklet for the elderly. Rev Bras Enferm. 2019;72(Suppl 2):214-20. doi: 10.1590/0034-7167-2018-0603

29. Jongstra S. Beishuizen C. Andrieu S. Barbera M. Dorp M.. Groep B. et al. Development and validation of an interactive internet platform for older people: the healthy ageing through internet counselling in the elderly study. Telemed J E-Health. 2017;23(2):96-104. doi: 10.1089/ tmj.2016.0066

30. Vanoh D. Ishak IH. Shahar S. Manaf ZA. Mohamad Ali N. Mohd Noah SA. Development and assessment of a web-based intervention for educating older people on strategies promoting healthy cognition. Clin Interv Aging. 2018;13:1787-98. doi: 10.2147/cia.s157324

31. Carneiro RV. Ishitani L. Usability aspects of mobile learning aimed at age-restricted users. Rev Bras Comp Aplic. 2014;6(1);81-94. doi: 10.5335/rbca.2014.3426

32. Cordeiro LI. Lopes TO. Lira LEA. Feitoza SMS. Bessa MEP. Pereira MLD. et al. Validation of educational booklet for HIV/Aids prevention in older adults. Rev Bras Enferm. 2017;70(4):775-82. doi: 10.1590/0034-7167- 2017-0145

33. Schepens SL. Panzer V. Goldberg A. Randomized controlled trial comparing tailoring methods of multimedia-based fall prevention education for community-dwelling older adults. Am J Occup Ther. 2011;65(6):702-9. doi: 10.5014/ajot.2011.001180

34. Pueyo-Garrigues M. Whitehead D. Pardavila-Belio MI. Canga-Armayor A. Pueyo-Garrigues S. Canga-Armayor N. Health education: a Rogerian concept analysis. Int J Nurs Stud. 2019;94:131-8. doi: 10.1016/j.ijnurstu.2019.03.005

35. Eltorai AE. Sharma P. Wang J. Daniels AH. Most american academy of orthopaedic surgeons' online patient education material exceeds average patient reading level. Clin Orthop Related Res. 2015;473(4):1181-6. doi: 10.1007/s11999-014-4071-2

36. Heim N. Faron A. Fuchs J. Martini M. Reich RH. Löffler K. Comprehensibility of online-based patient education material in ophthalmology. Ophthalmologe. 2017;114(5):450-6. doi: 10.1007/s00347-016-0367-9

37. Ximenes MA. Fontenele NA. Bastos IB. Macêdo TS. Galindo Neto NM. Caetano JA. et al. Construction and validation of educational booklet content for fall prevention in hospitals. Acta Paul Enferm. 2019;32(4):433-41. doi: 10.1590/1982-0194201900059

38. Abbasi M. Eslami S. Mohammadi M. Khajouei R. The pedagogical effect of a health education application for deaf and hard of hearing students in elementary schools. Electr Phys. 2017;9(9):5199-205. doi: 10.19082/5199 